\title{
Das \\ chemische Element seine Wandlung und sein Bau als Ergebnis der wissenschaftlichen Forschung
}

Von

\section{Dr. Willy Bein}

Mit 39 Figuren im Text

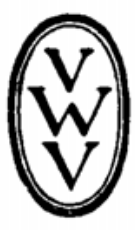

Leipzig und Berlin 1920

Vereinigung wissenschaftlicher Verleger Walter de Gruyter \& Co. 
Alle Rechte, einschließlich des Übersetzungsrechts, vorbehalten.

Druck von Metzger \& Wittig in Leipzig. 